\title{
Evaluation of Efficacy about Disinfectants in Biological Containment Facilities
}

\author{
Dong-Wook Kim ${ }^{1,2,3+}$, Kyung-Min Lee ${ }^{1,4+}$, Yeon-Joo Choi ${ }^{1,2}$, Byung-Nyun Chun ${ }^{5}$, Won-Jong Jang ${ }^{1,2 *}$ \\ 'Department of Microbiology, Konkuk University College of Medicine, Seoul 05029, Republic of Korea \\ ${ }^{2}$ Research Institute of Medical Science, Konkuk University College of Medicine, Seoul 05029, Republic of Korea \\ ${ }^{3}$ Institute of Environmental Protection and Safety, Seoul National University, Seoul 08826, Republic of Korea \\ ${ }^{4}$ International Vaccine Institute, Seoul 08826, Republic of Korea \\ ${ }^{5}$ Woojungbio Company, Gyeonggi Province 16229, Republic of Korea \\ these authors equally contributed to this work.
}

\begin{abstract}
Corresponding
Won-Jong Jang, Ph.D., Professor

University College of Medicine, 120 05029, Republic of Korea

Phone : +82-2-2030-7816

Fax : +82-2-2030-7845

E-mail : wjjang@kku.ac.kr
\end{abstract}

Department of Microbiology, Konkuk

Neungdong-ro, Gwangjin-gu, Seoul,

Received : January 31, 2021

Revised : March 16, 2021

Accepted : March 18, 2021

No potential conflict of interest relevant to this article was reported.

Copyright (C) 2021 Journal of Bacteriology and Virology

(C) This is an Open Access article distributed under the terms of the Creative Commons Attribution Non-Commercial

License

(http://creativecommons.org/

license/by-nc/3.0/).
In healthcare facilities, research facilities, and biology laboratories that handle biological agents, different types of disinfectants are used for sterilization and disinfection. In order to use disinfectants to prevent biological contamination and achieve the effective level of disinfection, accurate approaches should be considered such as selecting appropriate disinfectants and setting up effective disinfection conditions. This study performed an experiment by setting up a biologically contaminated surface in the facility such as the walls in order to examine the disinfection effects followed by the disinfectant and disinfection conditions. Geobacillus stearothermophilus, biological indicators, were used as a test organism of this study to verify the disinfection effects. Amongst what is used in many biological containment facilities, common disinfectants like DOCTOR SOLUTION, BruClean TBC ${ }^{\mathrm{TM}}$, TexQ ${ }^{\mathrm{TM}}$, ethanol, and sterile water were used. In addition, various practiced cleaning methods like spraying and wiping were applied by combining the condition of treating with the disinfectant for each condition and the disinfection level was verified synthetically. As a result of confirming the disinfection effects by combining different combinations of disinfectants and the disinfection sessions ( $1 \sim 5$ times), the findings suggest that disinfection was effective from the $1^{\text {st }}$ disinfection wiping with $70 \%$ ethanol. For the disinfection method, the condition of more than 1 time of wiping for disinfection was effective for the inactivation of infectivity for $G$. stearothermophilus by displaying disinfection effects. However, it was identified that only spraying DOCTOR SOLUTION is not effective for disinfection. We also carried out an additional experiment by investigating the impact of disinfectants (hydrogen peroxide, DOCTOR SOLUTION, BruClean $T_{B C} C^{T M}$, TexQ ${ }^{T M}$, ethanol, and peracetic acid) on various surface materials (epoxy, stainless steel, urethane, and lab benches) in the facility. As a result of identifying the changes in the surface material followed by the disinfectants, the experiment verified that it is safe in general concentration. Therefore, the findings of this study will provide much-needed information for the selection of appropriate disinfectants and disinfection methods when decontaminating bio-containment facilities in each institution.

Key Words: Sterilize, Disinfectants, Biological containment facilities 


\section{INTRODUCTION}

소독제는 병원, 실험실, 의약품 생산시설 등의 현장에서 병원성 미생물을 사멸시키는 약제로 사용되고 있다 (1). Block은 소독제를 미생 물 제어 수준에 따라 아포(spore)를 포함한 모든 미생물을 제거하는 멸균제(sterilant), 감염을 일으키는 세균, 진균, 바이러스를 사멸시 키는 소독제(disinfectant), 안전한 수준까지 미생물 수를 감소시키는 살균제(sanitizer)로 분류하였다 (2). 일반적으로 소독제로 사용하 는 화학물질은 소독 기전에 따라 미생물과 상호작용하여 미생물의 효소계를 불활성화시키는 차아염소산나트륨(sodium hypochlorite), 포비돈요오드(povidone iodine), 과산화수소(hydrogen peroxide), 과초산(peracetic acid) 등이 있고, 미생물 내에서 응고(coagulator)가 일어나게 하는 에틸알코올(ethyl alcohol), 클로르헥시딘(chlorhexidine), 제4급 암모늄 화합물(quaternary ammonium compound), 글루타알데하이드(glutaraldehyde) 등이 있다 (3). 소독제를 선택할 때는 오염 미생물 종류와 농도, 소독 방법(분무, 닦아내기, 침지, 관 류, 훈증 등)과 조건(접촉시간, 적정농도, 외부온도, 습도 등), 안전성(인체 유해성, 환경오염, 소독대상물 영향 등), 경제성, 편리성 등 다 양한 요소를 고려해야 한다 $(4,5)$. 세균, 바이러스 등의 병원체를 취급하는 실험실과 감염 환자를 치료하는 의료 시설, 축산 사육에 필요 한 농림 축산시설 등에서는 사람 감염, 동물 감염, 시설 내부 오염과 같은 생물 위해가 발생할 수 있으므로 이에 대한 적절한 오염 제거 및 생물안전 확보가 필요하다 (6-9). 국내 대표적인 실험실 감염사례는 실험동물을 취급하던 연구자가 Hantavirus에 감염되었고 Dengue virus를 취급하던 실험종사자의 감염사고도 있었다 $(10,11) .2015$ 년 5월 아라비아반도(Arabian Peninsula)에서 돌아온 한국인 여행 자가 신·변종 병원체인 메르스 코로나바이러스(Middle East Respiratory Syndrome coronavirus; MERS-CoV)에 감염된 사례가 있었 다. 그로 인해 국내에 환자가 다수 발생하였고 환자를 치료하던 병원시설에서 바이러스가 전파되어 환자와 의료진이 감염되었다. 그 당시 병원시설에서는 생물 위해 제거를 위해 건물을 폐쇄하고 응급실, 본관, 별관, 병동 등 오염구역을 나누어 소독하고 멸균하였다 (12-15). 또 한 2015년 10월 국내 대학 실험실에서 원인 불명의 집단 폐렴 감염사건이 발생하였다. 이는 방선균(Saccharopolyspora rectivirgular)으 로 추정되는 병원체가 전파되어 발생한 실험실 획득 감염(laboratory-associated infection; LAI) 으로, 당시 역학조사와 동시에 실험실 을 포함한 해당 건물을 생물학적 멸균 등의 방법으로 오염 제거를 한 국내 첫 사례로 보고되었다 $(16,17)$. 특히 2019년 12월 중국 우한 (Wuhan, China)에서 시작한 세계적 대유행(pandemic) 코로나바이러스감염증-19(Coronavirus disease 2019; COVID-19)가 국내로 유입되어 질병이 발생하였고 지역사회까지 전파되는 등 심각한 상황이 초래되었다 (18-21). 병원체가 노출되는 의료기관 시설에서는 감 염 확산 방지 등을 위하여 소독이나 멸균을 철저히 해야 하고 오염 상황에 따라서 학교 등과 같은 일반적인 집단 시설에도 해당이 될 것이 다. 국외에서도 생물학적 오염 시설의 오염 제거 사례가 확인되었다. 2001년 미국 탄저균(Bacillus anthracis) 생물테러 사건에서 제독으 로 사용되었다고 알려진 메틸브로마이드(methyl bromide)는 몬트리올 의정서(Montreal Protocol)에 근거하여 현재는 전 세계적으로 사용이 금지되어 있다 (22). 2003년 싱가포르에서 발생한 사스 코로나바이러스(Sever Acute Respiratory Syndrome coronavirus; SARS-CoV) 확산의 원인으로 병원에 초점을 맞추어 80개의 병실로 구성된 병원 병동의 여덟 곳을 생물학적 멸균 처리하였으며, 병실 멸 균하는데 room bio-decontamination service (RBDS)를 통해 과산화수소 증기에서 나오는 free radical의 살균력을 이용하였다 (23). 2014년 아프리카 시에라리온(Sierra Leone)에서 본국으로 송환된 영국 에볼라 바이러스 질병(Ebola virus disease; EVD) 환자를 간호 했던 근무자 및 오염 구역에 대해서 과산화수소 증기를 이용한 생물학적 멸균하였다. 이는 영국의 건강과 안전 본부(Health and Safety Executive; HSE)에 의해 승인된 프로토콜을 사용한 런던의 '높은 수준의 분리 단위(high level isolation unit; HLIU)'의 오염 제거 사례 로 보여 주고 있다 $(24,25)$. 이러한 감염 가능성이 있는 병원체의 비의도적인 유출과 병원체로 인한 질병 발생 등으로 생물학적 오염 발 생 시설은 소독 등의 오염 제거를 제대로 조치하지 않으면 심각한 문제가 발생할 수 있음을 보여 준다. 따라서 본 연구에서는 국내에서 사 용되는 다양한 소독제를 확인하고 그 특성을 분석하였으며, 그 중 일부 소독제를 선택하여 여러 가지 조건으로 소독하여 소독 효과를 확 인하였다. 또한, 일반적인 실험실, 병원, 장비 등의 표면에 미치는 영향을 살펴보았다.

\section{소독제의 특성과 효과 분석}

소독제의 특성과 효과 분석은 국내에서 취급되고 있는 소독약품을 대상으로 실시하였다. 소독약품 정보 수집은 감염병의 예방 및 관리에 관한 법률(약칭: 감염병예방법)(법률 제17689호)'에 따라 방역1) 소독 시 사용 할 수 있는 감염병예방용 소독약품이 등록되어 있는 환경 부 생물환경안전정보시스템(http://ecolife.me.go.kr)으로부터 자료를 확보하였다. 소독제의 일반적인 특성은 Rutala등에 의해 다음과 같이 알려져 있다 $(26,27)$. 세균, 진균, 바이러스에는 큰 효과를 가지는 알코올계(alcohol) 소독제는 $70 \%$ 에틸알코올, $20 \%$ 이소프로 필알코올(isopropyl alcohol) 농도의 수용액으로 사용하면 효과가 있고 에틸알코올의 경우 외피비보유(non-enveloped) 바이러스를 사

1) 방역이란 감염병 따위를 퍼지지 않도록 예방하는 것을 말함 
멸시키지 못한다 (26). 또한 알코올계는 휘발성과 인화성이 있어 화기 근처에서 사용을 금해야 하고 고무를 경화시키고 일부 접착제를 녹 이는 성질이 있다 (27). 염소계(chlorine)의 대표적인 물질인 차아염소산나트륨은 멸균수로 희석하여 농도를 다양하게 사용이 필요할 때 좋으나 금속에는 부식되는 성질이 있어 표면이 금속인 곳(스테인리스 스틸 작업대, 원심분리기 등)에서는 사용하지 말아야 한다. 또한 폼 알데하이드(formaldehyde)와 반응하게 되면 발암성 물질을 생성하므로 두 화합물의 접촉을 피하게 하고 유기물로 인해 쉽게 비활성화 가 되므로 사용 당일 소독 용액을 만들어 사용한다. 그 밖에 $25 \%$ 유효 염소를 함유한 클로라민(chloramine)과 염소가 필요로 하는 수준 보다 낮은 농도에서도 효과를 보고자 할 때는 이산화염소(chlorine dioxide)가 좋다. 알데하이드계(aldehyde)에서는 폼알데하이드가 $37 \%$ 함유한 수용액의 포르말린을 사용하고 있다. 스테인리스 스틸 싱크대 등과 같이 금속 부식성에 해당되는 경우에는 글루타알데하이 드( $2 \%$ 유효농도)는 사용하는 것이 괜찮다. 하지만 인체 독성이 있어 주의해야 한다. 결핵균(Mycobacterium tuberculosis) 제거용으로 폐놀계(phenolic) 소독제는 적합하나 냄새가 강하고 안전하지 않아 사용에 조심해야 한다. 영양세균, 지질 함유 바이러스에 활성이 우수 한 것은 제4급 암모늄 화합물이다. 그러나 아포에는 효과적이지 않고 유기물에 의해 쉽게 비활성화가 된다. 고농도일 경우 인체 자극과 독성을 나타내므로 충분히 희석한 소독액 사용을 권장하고 실제로는 0.5-1\% 농도가 적합하다. 세균, 아포, 바이러스 등에 효력이 강한 것은 요오드계가 좋으나 단점으로는 금속을 부식시킬 수 있어 알루미늄, 구리 재질은 사용을 피해야 한다. 일반세균, 진균, 결핵균, 바이 러스 및 아포까지 사멸 가능한 것은 과산화 물질이다. 실제는 $30 \%$ 원액을 멸균수로 희석하여 $3 \%$ 용액을 사용하며 염소계 소독제보다 비교적 안전하나 금속(알루미늄, 구리, 황동, 아연 등)에는 폭발하는 성질을 가진다. 이러한 화학 소독제로부터 사용자에게 영향을 주는 인체 및 화학적 위해 등도 확인이 필요하다 (28). 국내 소독제는 「감염병의 예방 및 관리에 관한 법률」(약칭: 감염병예방법)(법률 제 17689 호)'에 따른 감염 예방용으로 사용할 수 있는 환경부에 승인된 소독약품(2020년 3월 13일 기준)은 환경부 생물환경안전정보시스 템(http://ecolife.me.go.kr)으로부터 '안전확인대상생활화학제품' 총 1,686종(2019년 식품의약품안전처에서 이관된 의약외품 감염병 예방용 살균소독제 포함)이 확인되었다. 실제 현장에서 가장 흔히 사용하는 소독제는 Bae 등에 의해 주요 성분이 sodium hypochlorite, sodium dichloroisocyanurate, peracetic acid, quaternary ammonium cation, alcohol, ammonium bicarbonate, peroxyacetic acid, idophor 등이 알 수 있었으며 그 주요 성분에 의한 분류는 염소계, 제4급 암모늄 화합물계, 알코올계, 과산화수소계, 요오드계 등으 로 나타났다 (29). 「감염병예방법」(법률 제17689호)'에 근거하여, 의무소독 대상시설에서 사용할 수 있는 석탄산수(석탄산 $3 \%$ 수용 액)(phenol), 크레졸수(크레졸액 3\% 수용액)(methyl phenol), 승홍수(승홍 $0.1 \%$, 식염수 0.1\%, 물 99.8\% 혼합액)(mercury chloride II), 생석회(대한약전 규격품)(calcium oxide), 크롤칼키수(크롤칼키 5\% 수용액)(calcium hypochlorite), 포르말린(대한약전 규격 품)(formalin), 석탄산 3\% 수용액에 해당하는 소독력이 있는 약제 등이 지정되어 있다. 국내에서 취급되는 소독제의 종류, 사용원료, 살 균대상 등을 분석한 결과는 미생물의 소독제 내성에 적합한 유효성분을 선택하고 있었고 효과를 나타낼 수 있는 간단한 손 소독제에서 살 균 및 멸균을 위한 산업적 용도의 살균제까지 다양한 형태의 소독제 제품들이 사용되고 있었다. 주로 사용되는 원료, 유효성분(active ingredient)로는 과황산암모늄(ammonium persulfate), $80 \%$ 염화-n-알킬디메틸에틸벤질암모늄·염화알킬벤질디메틸암모늄(1:1) 액, 벤잘코늄염화물(benzalkonium chloride), 염화벤제토늄 농축액(benzethonium chloride concentrate), 구연산(citric acid), 디데 실디메틸암모늄염화물(didecyldimethylammonium chloride; DDAC) $50 \%$ 에틸알코올, 이소프로필알코올), 시트르산수화물 (sodium citrate hydrate) 등이 확인되었다. 살균대상으로는 세균에서 바이러스까지 다양한 타깃(kill claim list)을 대상으로 하고 있어 광범위 살균제 기능을 갖는 제품이 주를 이루고 있었으며 약 50 여종의 원료를 가지고 살균제의 다양한 제품명으로 출시되고 있었다. $\mathrm{CDC}$ 의 살균 화학물질에 의한 내성(resistance) 미생물 6군(bacterial spores 등) 과 대표 미생물(Bacillus subtilis 등)을 활용하여 국내 판매되는 소독제의 대표 제품명(trade name), 유효성분(active ingredient), 희석 농도(dilution concentration) 등의 정보를 나눌 수 있었으며, 일반적인 미생물 저항성에 따른 제품 소독 멸균의 수준을 확인할 수 있었다 $(6,30)$ (Table 1).

\section{MATERIALS AND METHODS}

\section{시험균주 및 균주 배양}

본 연구에서 사용한 시험균주는 멸균력 검증을 위해 미국약전(United States Pharmacopoeia; UPS) 28개정판과 국내 KS규격(KS P ISO 14161)에서 지정된 Geobacillus stearothermophilus (ATCC 7953), Sterikon ${ }^{\circledR}$ plus Bioindicator $\left(5 \times 10^{5}-1 \times 10^{7}\right.$ spores/2 $\mathrm{ml}$, Merk, Darmstadt, Germany) 원액을 구매하여 사용하였다. G. stearothermophilus를 증균을 위하여 영양배지(Difco ${ }^{\mathrm{TM}}$ nutrient broth, $\mathrm{BD}$ ) 사용하여 $55^{\circ} \mathrm{C}$ 배양조건의 배양기에서 진탕 배양하였다. 전체균농도가 $4.34 \times 10^{7}$ (CFU/ml)인 G. stearothermophilus 배 양액을 아포 발생을 유도 $\left(80^{\circ} \mathrm{C}, 20\right.$ 분, 중탕가열) 하여 아포가 $0.17 \%$ 함유된 것을 사용하였다. 
Table1. Effectiveness and microbial resistance of representative disinfectants marketed in Korea (as of March, 2020)

\begin{tabular}{|c|c|c|c|c|c|}
\hline Resistance $^{a}$ & Microorganism & Examples $^{\mathrm{b}}$ & $\begin{array}{c}\text { Trade name } \\
\text { (Manufacturer) } \\
\end{array}$ & $\begin{array}{c}\text { Active ingredient } \\
\text { (Dilution concentration, v/v) }\end{array}$ & $\begin{array}{l}\text { Disinfectant } \\
\text { Category }\end{array}$ \\
\hline 1 & Bacterial spores & $\begin{array}{l}\text { Bacillus subtilis, } B . \\
\text { cereus, Clostridium } \\
\text { sporogenes, } C . \\
\text { perfrigens }\end{array}$ & $\begin{array}{l}\text { Rely+On }{ }^{\mathrm{TM}} \text { Virkon }{ }^{\circledR} \\
\text { (Pharmcle) } \\
\text { ZAPS Disinfectant } \\
\text { Powder } \\
\text { (Pharmcle) }\end{array}$ & $\begin{array}{c}\text { Persulfate compound } \\
\text { (1\%) } \\
\text { Monosulfate compound } \\
\text { Malic acid } \\
(1 \%)\end{array}$ & $\begin{array}{l}\text { Peroxygen } \\
\text { compound } \\
\text { Peroxygen } \\
\text { compound }\end{array}$ \\
\hline \multirow{3}{*}{2} & \multirow{3}{*}{ Mycobacteria } & \multirow{3}{*}{$\begin{array}{c}\text { Mycobacterium } \\
\text { tuberculosis var. bovis, } \\
\text { M. terrae, } \\
\text { Nontuberculous } \\
\text { mycobacteria }\end{array}$} & $\begin{array}{c}\text { CaviCide }^{\mathrm{TM}} \\
\text { (We'zen HealthCare) }\end{array}$ & $\begin{array}{l}\text { Isopropyl alcohol } \cdot \text { benzethonium } \\
\text { chloride concentrate } \\
(0 \%)\end{array}$ & $\begin{array}{l}\text { Alcohol, } \\
\text { QAC }\end{array}$ \\
\hline & & & $\begin{array}{l}\text { Melacid } \\
\text { (Huen) }\end{array}$ & $\begin{array}{c}\text { Citric acid } \\
(1 \%)\end{array}$ & Acid \\
\hline & & & $\begin{array}{l}\text { SURFA'SAFE } \\
\text { (CL Haijin) }\end{array}$ & $\begin{array}{c}\text { Didecyldimethylammonium } \\
\text { chloride (DDAC) } 50 \% \cdot \\
\text { Polyhexamethylene biguanide } \\
\text { hydrochloride (PHMB) } 20 \% \\
(0 \%)\end{array}$ & QAC \\
\hline \multirow[b]{2}{*}{3} & \multirow{2}{*}{$\begin{array}{l}\text { Nonlipid } \\
\text { (noneveloped) } \\
\text { viruses, Small } \\
\text { viruses }\end{array}$} & \multirow{2}{*}{$\begin{array}{c}\text { Poliovirus, } \\
\text { Papillomaviruses, } \\
\text { Coxsackievirus, } \\
\text { Rhinovirus }\end{array}$} & $\begin{array}{c}\text { D-125 } \\
\text { (Sam Hyun Chemical) }\end{array}$ & $\begin{array}{c}80 \% \text { n-Alkyldimethyl ethyl benzyl } \\
\text { ammonium chloride · Alkyldimethyl } \\
\text { benzyl ammonium chloride }(1: 1) \\
(1.54 \%)\end{array}$ & QAC \\
\hline & & & $\begin{array}{l}\text { DOCTOR SOLUTION } \\
\text { HSB021 } \\
\text { (Hansung Bio-Chem) }\end{array}$ & $\begin{array}{c}80 \% \text { n-Alkyldimethyl ethyl benzyl } \\
\text { ammonium chloride } \text { Alkyldimethyl } \\
\text { benzyl ammonium chloride }(1: 1) \\
(1.54 \%)\end{array}$ & QAC \\
\hline 4 & Fungi & $\begin{array}{l}\text { Trichophyton spp., } \\
\text { Cryptococcus spp., } \\
\text { Candida spp. }\end{array}$ & $\begin{array}{l}\text { ANIOSURF Premium } \\
\text { (CL Haijin) }\end{array}$ & $\begin{array}{c}\text { Chlorhexidine Gluconate } \cdot \\
\text { Polyhexamethylene biguanide } \\
\text { hydrochloride (PHMB) } 20 \% \cdot \\
\text { didecyldimethylammonium } \\
\text { chloride (DDAC) } 50 \% \\
(0.25 \%)\end{array}$ & QAC \\
\hline \multirow[b]{3}{*}{5} & \multirow[b]{3}{*}{$\begin{array}{l}\text { Vegetative } \\
\text { bacteria }\end{array}$} & \multirow{3}{*}{$\begin{array}{c}\text { Pseudomonas } \\
\text { aeruginosa, } \\
\text { Staphylococcus aureus, } \\
\text { Salmonella choleraesuis, } \\
\text { Enterococci }\end{array}$} & $\begin{array}{l}\text { NOBAC Citric } \\
\text { (Heat Runner) }\end{array}$ & $\begin{array}{l}\text { Citric Acid Hydrate } \\
(0 \%)\end{array}$ & Acid \\
\hline & & & $\begin{array}{c}\text { BIOCLEAN } \\
\text { (Jayeon Nature Science) }\end{array}$ & $\begin{array}{c}\text { Citric Acid Hydrate } \\
(1 \%)\end{array}$ & Acid \\
\hline & & & $\begin{array}{l}\text { Distel } \\
\text { (HP\&C) }\end{array}$ & $\begin{array}{c}\text { 20\% Polyhexamethylene } \\
\text { biguanide hydrochloride (PHMB) } \\
\text { didecyldimethylammonium } \\
\text { chloride (DDAC) } 50 \% \cdot \\
\text { Benzalkonium chloride } 50 \% \\
(0.5 \%)\end{array}$ & QAC \\
\hline \multirow{4}{*}{6} & \multirow{4}{*}{$\begin{array}{l}\text { Lipid } \\
\text { (enveloped) } \\
\text { viruses, } \\
\text { Medium-size } \\
\text { viruses }\end{array}$} & \multirow{4}{*}{$\begin{array}{c}\text { Herpes simplex virus, } \\
\text { Cytomegalovirus, } \\
\text { Respiratory syncytial } \\
\text { virus, Hepatitis B virus, } \\
\text { Hepatitis C virus, Human } \\
\text { immunodeficiency virus, } \\
\text { Hantavirus, Ebola virus }\end{array}$} & $\begin{array}{l}\text { DA CLEAN } \\
\text { (Deborah) }\end{array}$ & $\begin{array}{l}\text { Ethyl alcohol } \\
(0 \%)\end{array}$ & Alcohol \\
\hline & & & $\begin{array}{c}\text { ED Wipes } \\
\text { (Wooil C\&Tech) }\end{array}$ & $\begin{array}{l}\text { Benzalkonium chloride } 50 \% \\
\qquad(0 \%)\end{array}$ & QAC \\
\hline & & & $\begin{array}{l}\text { Viraclean }^{\circledR} \\
\text { (PIC Consulting) }\end{array}$ & $\begin{array}{l}\text { Benzalkonium chloride } \\
(0 \%)\end{array}$ & QAC \\
\hline & & & $\begin{array}{l}\text { PeraCide } \\
\text { (Rotor) }\end{array}$ & $\begin{array}{l}\text { Peroxyacetic Acid } \\
(1 \%)\end{array}$ & Acid \\
\hline
\end{tabular}

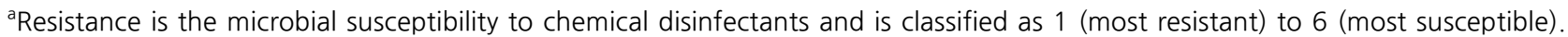
${ }^{b}$ Microorganism and examples are partially modified by The United States Department of Health and Human Services, Center for Disease Control and Prevention (CDC), National Institutes of Health. Biosafety in Microbiological and Biomedical Laboratories (BMBL) $5^{\text {th }}$ ed. Washington D.C.: CDC/NIH, 2009. 'Disinfectant category is classified according to chemical properties. QAC; Quaternary ammonium compound. 


\section{소독제 및 효과 시험 방법}

소독제의 효과를 살펴보기 위해 다음과 같이 소독제를 선택하여 시험 균주에 대한 소독 효과를 확인하였다. 본 연구에서 사용한 소독제는 실제 현장에서 사용되는 것 들 중에서 대표로 사용되는 소독제인 닥터솔루션 살균소독액 HSB021 (80\% 염화-n-알킬디메틸에틸벤질암 모늄 n-Alkyldimethyl ethyl benzyl ammonium chloride · 염화알킬벤질디메틸암모늄 Alkyldimethyl benzyl ammonium chloride (1:1)액)(한성바이오켐, 충북), BruClean Tbc ${ }^{\mathrm{TM}}$ TX6466 disinfectant (48.21\% sodium dichloroisocyanurate) (Texwipe, North Carolina, USA), TexQ ${ }^{\circledR}$ TX651 disinfectant (quaternary ammonium compound) (Texwipe, North Carolina, USA), 30\% 과산화 수소(Merk, New Jersey, USA), 에틸알코올(Sigma-Aldrich®, USA)을 구매하였다. 시험 소독 용액은 제4급 암모늄 화합물 2종, 염소 계 1 종, 알코올계 1 종, 과산화물 1 종 등 총 5 종의 소독제를 사용하였고, 제조사 회사에서 권장하는 용법, 용량을 기준으로 제조하여 시험 에 사용하였다.

소독제 효과 시험은 ‘의료기기용 살균소독제 유효성평가 가이드라인(식품의약품안전처)’에 따라 표면 소독(분무, 닦아 내기, 훈증)을 하였 다. 본 시험은 시험균주 도포, 소독 등 오염 제거, 시료 채취, 시료 배양 후 균 생성 확인 순으로 진행하였다.

시험균주 도포는 실험실 벽면(우레탄 판넬 재질)에 적색 테이프를 이용하여 30 개 구획(가로 $30 \mathrm{~cm} \times$ 세로 $30 \mathrm{~cm}$ )을 표시하였고 시험균 주 G. stearothermophiolus가 담겨 있는 분무기(hand sprayer)를 이용하여 각 구획에 3회 분사(1회 분사량: 약 1,010 $\mu$ )한 후에 건조 시켰다. 이 방법을 3회 반복하여 실시하였다.

소독 등 오염 제거는 Table 2에 나와 있는 다양한 소독제 조합으로 실시하였다. 대조군인 경우에는 균액을 분무하고 아무런 처치를 하지 않는 것으로 정하였으며 다음과 같은 방법으로 소독과 제균 하였다. 소독 용액이 분사된 부직포 와이퍼(AlphaWipe ${ }^{\circledR}$ TXA2169 polyester wiper [Texwipe, North Carolina, USA]) 2장으로 시험균주가 도포된 구획에 대해서 수평으로 순차적으로 닦아 내고, 와이퍼 를 닦은 부위를 안쪽으로 1회 접은 후 수직으로 닦아낸 다음 사용한 와이퍼를 1회 더 접은 후 대각선으로 닦아 냈다. 2, 3차 소독 시 부직 포 와이퍼로 실시하였고 최종 소독 처리 시에는 TechniCloth ${ }^{\circledR}$ TXA809 polyester / cellulose wiper (Texwipe, North Carolina, USA) 에서 구매한 폴리에스터 와이퍼를 사용하였다. '닥터솔루션 살균소독액'은 실제 초미립자분사(ultrafine particle sprayer) 형식으로 사용 하는 소독제이므로 분무 후 닦아 내지 않고도 소독 효과를 확인할 수 있었다.

시료채취(swabbing)는 $0.01 \mathrm{M}$ phosphate buffered saline (PBS), pH 7.2-7.4에 적신 멸균 거즈 $(5 \times 5 \mathrm{~cm})$ 를 사용하여 수평 방향으 로 's'자를 그리며 서로 겹쳐서 닦아 내고, 거즈를 닦은 부위를 안쪽으로 1회 접은 후 's'자를 그리며 구획 내 시료를 닦아 냈다. 이어 거즈 를 1회 더 접은 후 대각선으로 ' $\mathrm{S}$ '자를 그리며 같은 구획을 닦아 내고 거즈를 $20 \mathrm{ml}$ 배지(Difco' ${ }^{\mathrm{TM}}$ nutrient broth, $\mathrm{BD}$ )가 들어 있는 검체 배양용 튜브(conical tube $5005050 \mathrm{m \ell}$ PP /HDPE (SPL Life Sciences, 경기)에 넣어 보관하였다.

채취한 시료를 배양 후 균 생성 확인은 phenol red를 지시제로 사용한 배양 검사로 하였다. 시료가 들어 있는 튜브에서 $100 \mu \ell$ 와 $1 / 20$ 희석액 $100 \mu \ell$ 를 취하여 각각 Phenol red-nutrient broth (P8976 Phenol Red Broth Base, Sigma-Aldrich ${ }^{\circledR}$, USA)에 넣고 $55^{\circ} \mathrm{C}^{\circ}$ 에 서 36시간 배양하였다. 1번 시료는 추가로 $10^{-1}, 10^{-2}, 10^{-3}, 10^{-4}$ 로 희석하고 3번 시료는 $10^{-1}, 10^{-2}, 10^{-3}$ 으로 희석하여 nutrient agar plate에 $0.5 \mathrm{~m}$ 씩 도말 하여 배양하였다. Phenol red-nutrient broth 배양에서 양성반응이 나온 시료는 nutrient agar plate에 도말 하 여 $55^{\circ} \mathrm{C}$ 에서 36 시간 배양하였다.

\section{소독제에 따른 표면 재질의 영향 확인}

소독제가 실험실 혹은 실내 장비 및 기구 표면에 미치는 영향을 다음과 같이 확인하였다. 본 연구에 사용한 표면 재질은 실험실, 의료기관 시설 등에서 흔하게 접할 수 있고 가장 많이 사용되는 에폭시(노루페인트, DHDC-6800 D-80680[DV] 에폭시), 스테인리스 스틸 (PRIMUS Sterilizer, 304 SUS), 우레탄(포스코, N53 (POS-PVDF) 불소강판), 실험대 상판(WILSONART-CHEMSURF, PHENOLIC LAMINATE)로 선정하였다 (31) (Table 3). 각 표면 재질에 따른 소독제 반응 검사는 Table 4의 소독 용액을 분무 후 건조 시킨 뒤 형태 변화를 다음과 같이 확인하였다.

각 표면 재질에 멸균수를 적신 부직포를 이용하여 표면을 닦아 건조 시킨 후 각 소독 용액을 3 회 분무(1회 분사량: 약 $1,010 \mu \ell)$ 하였고 건 조 후 관찰하였다. 그 과정을 7회 반복한 후 부직포에 멸균수를 묻혀 표면을 세정 후 최종 변화를 눈으로 확인하고 사진 촬영하였다. 
Table 2. Disinfectant solution condition used in this study

\begin{tabular}{|c|c|c|c|c|c|c|c|}
\hline \multirow{2}{*}{ Test No. } & \multicolumn{5}{|c|}{ Disinfectant treatment (test matrix) } & \multirow{2}{*}{ Fumigation } & \multirow[b]{2}{*}{ Remark } \\
\hline & $1^{\text {st }}$ & $2^{\text {nd }}$ & $3^{\text {rd }}$ & $4^{\text {th }}$ & $5^{\text {th }}$ & & \\
\hline 1 & - & - & - & - & - & - & Control 1 \\
\hline 2 & - & - & - & - & - & $30 \% \mathrm{HP}$ & Control 2 \\
\hline 3 & SW & - & - & - & - & - & Control 3 \\
\hline 4 & SW & - & - & - & - & $30 \% \mathrm{HP}$ & Control 4 \\
\hline 5 & DD & - & - & - & - & - & - \\
\hline 6 & $\mathrm{BD}$ & - & - & - & - & - & - \\
\hline 7 & TD & - & - & - & - & - & - \\
\hline 8 & $70 \% \mathrm{EtOH}$ & - & - & - & - & - & - \\
\hline 9 & DD & SW & - & - & - & - & - \\
\hline 10 & DD & $70 \% \mathrm{EtOH}$ & - & - & - & - & - \\
\hline 11 & DD & $70 \% \mathrm{EtOH}$ & SW & - & - & - & - \\
\hline 12 & $\mathrm{BD}$ & SW & - & - & - & - & - \\
\hline 13 & TD & SW & - & - & - & - & - \\
\hline 14 & DD & $70 \% \mathrm{EtOH}$ & - & - & - & - & - \\
\hline 15 & $B D$ & $70 \% \mathrm{EtOH}$ & - & - & - & - & - \\
\hline 16 & $B D$ & $70 \% \mathrm{EtOH}$ & SW & - & - & - & - \\
\hline 17 & TD & $70 \% \mathrm{EtOH}$ & - & - & - & - & - \\
\hline 18 & TD & $70 \% \mathrm{EtOH}$ & SW & - & - & - & - \\
\hline 19 & DD & $\mathrm{BD}$ & - & - & - & - & - \\
\hline 20 & DD & $\mathrm{BD}$ & SW & - & - & - & - \\
\hline 21 & DD & $\mathrm{BD}$ & $70 \% \mathrm{EtOH}$ & - & - & - & - \\
\hline 22 & DD & $\mathrm{BD}$ & $70 \% \mathrm{EtOH}$ & - & - & - & - \\
\hline 23 & $\mathrm{BD}$ & TD & - & - & - & - & - \\
\hline 24 & $\mathrm{BD}$ & TD & SW & - & - & - & - \\
\hline 25 & $\mathrm{BD}$ & TD & $70 \% \mathrm{EtOH}$ & - & - & - & - \\
\hline 26 & $\mathrm{BD}$ & TD & $70 \% \mathrm{EtOH}$ & SW & - & - & - \\
\hline 27 & DD & $\mathrm{BD}$ & TD & - & - & - & - \\
\hline 28 & DD & $\mathrm{BD}$ & TD & SW & - & - & - \\
\hline 29 & DD & $\mathrm{BD}$ & TD & $70 \% \mathrm{EtOH}$ & - & - & - \\
\hline 30 & DD & $\mathrm{BD}$ & TD & $70 \% \mathrm{EtOH}$ & SW & - & - \\
\hline
\end{tabular}

Abbreviations: $\mathrm{BD}=$ BruClean disinfectant (spray and wipes), $\mathrm{DD}=\mathrm{DOCTOR}$ SOLUTION disinfectant (spray), EtOH= Ethyl alcohol (spray and wipes), HP= Hydrogen peroxide (spray and wipes), SW= Sterile water (spray and wipes), TD= TexQ disinfectant (spray and wipes).

Table 3. Typical surfaces to be decontaminated by disinfectants in a facility area

\begin{tabular}{cc}
\hline Material $^{a}$ & Applicationa \\
\hline Stainless steel 304L and 316L grades & Work surfaces, filling equipment and tanks \\
Plastic, vinyl & Windows and vessels \\
Plastic, polycarbonate & Curtains \\
Lexan $^{\circledR}$ (plexiglass) & Insulation coating \\
Epoxy-coated gypsum $^{\text {Splass }}$ & Shields \\
Fiberglass-reinforced plastic & Walls and ceilings \\
Tyvek ${ }^{\circledR}$ & Wall paneling \\
Terrazzo tiles & Equipment wraps \\
Phenolic laminate, Cerastone, Melamin & Floors \\
Uretane & Laboratory table \\
\hline
\end{tabular}

${ }^{a}$ Material and application are cited or slightly modified in The United States Pharmacopeial (USP), General Information 1072, Disinfectants and Antiseptics. 
Table 4. Disinfectant solutions used in this study

\begin{tabular}{cc}
\hline Test No. & Disinfectant solutions \\
\hline 1 & $30 \%$ hydrogen peroxide \\
2 & $30 \%$ hydrogen peroxide (10 ${ }^{-1}$ dilution) \\
4 & BruClean disinfectant \\
5 & TexQ disinfectant \\
6 & DOCTOR SOLUTION disinfectant \\
7 & Peracetic acid (1/300 dilution) \\
8 & $70 \%$ ethyl alcohol \\
9 & $30 \%$ hydrogen peroxide (fumigation 1 time) \\
\hline
\end{tabular}

\section{RESULTS}

\section{소독제의 시험 효과}

시험균주를 분무하고 건조 시킨 후 다양한 소독제의 조건 및 횟수를 달리하여 소독한 결과를 Table 5에 나타냈다. 시험은 2회 반복하여 실시하였다. 1차 시험에서 소독한 이후 채취한 검체를 $55^{\circ} \mathrm{C}, 36$ 시간 배양 결과 $1,3,5,15$ 번 조건에서 Phenol red 지시제를 첨가한 배 양액 색이 노란색으로 변화하여 균이 증식함을 확인하였다. 균 증식이 확인된 배양액을 nutrient agar plate에서 배양한 시험에서는 1, 3,5 번에서 콜로니(colony)를 확인할 수 있었다. 1 번은 소독제와 물리적인 제거를 실행하지 않은 대조군 조건이며, 3 번은 증류수를 사용 하여 닦아 낸 조건으로 소독제 미처리 대조군 조건이다. 2차 시험에서는 3번 대조군 처리를 생략하였으며, 배양 결과 1, 5번 조건에서만 색이 노란색으로 변하여 Phenol red 양성 반응을 보였고, nutrient agar plate 배양 시험에서도 마찬가지로 1번과 5번에서만 양성반응 이 나왔다. 1차 시험에서 15번의 양성반응은 14번의 '닥터솔루션 살균소독액(DOCTOR SOLUTION disinfectant; DD)' 분무 시에 균 액 이 밑으로 흘러내림으로써 나타난 양성반응으로 추정된다. 또한 1차, 2 차 시험 결과 모두 5번에서 양성반응이 나타났으므로 '닥터솔루션 살균소독액' 분무하는 것만으로는 검사대상 균주를 완전히 소독하지 못하는 것으로 확인하였다. ‘닥터솔루션 살균소독액’은 실제 초미립자 분사 형식으로 사용하는 소독제이며, 같은 조건의 분무는 완전한 소독이 이루어지지 않았으며, 'BruClean 소독제(BruClean disinfectant; $\mathrm{BD}), \mathrm{TexQ}$ 소독제(TexQ disinfectant; TD), $70 \%$ 에틸알코올' 등을 충분히 적셔 3회 닦아 내는 조건은 1회 수행하는 것만으로도 검사대 상 균주를 사멸 혹은 제균 가능함을 확인하였다(Table 5).

\section{소독제에 따른 표면 재질의 영향}

소독제가 시설, 장비, 기구 등의 표면에 미치는 영향을 확인한 결과는 다음과 같다. $30 \%$ 과산화수소(10-1 희석), BruClean, TexQ, 닥터 솔루션 살균소독액, 과초산(1/300 희석), $70 \%$ 에틸알코올, 과산화수소(훈증 1회), 멸균수 등의 소독제와 대조 물질을 7회까지 분무 처 리하고 그 영향을 확인한 결과 에폭시, 스테인리스 스틸, 우레탄, 실험대 상판 등의 재질에 변화가 전혀 없었다. 하지만, $30 \%$ 과산화수소 원액을 같은 조건으로 처리한 결과는 표면 재질에 영향 주는 것으로 나타났다(Fig. 1). 에폭시 재질에서는 1회 분무 뒤 건조 후에 곧바로 색의 변조가 나타났고, 7회까지 분무하여 건조 후 멸균수로 세정 결과 누렇게 색이 변조된 것이 관찰되었다. 우레탄에서는 4회 분무 후부 터 표면이 벗겨지는 현상이 관찰되었다. 또한 실험대 상판에서는 3회 분무 후부터 하얗고 볼록하게 기포가 올라오는 현상이 나타났고, 7 회 분무 후에는 울퉁불퉁하게 표면이 일어남을 확인할 수 있었다. $30 \%$ 과산화수소 소독제는 분무 형태로 처리하였을 경우 표면 재질에 영향을 미칠 수 있는 것으로 확인되었고, 1 회 훈증 경우에는 변화가 없음을 확인하였다. 본 연구에서는 분무처리, 훈증 등 분무 확산 방식 과 흡착 누적에 따라 표면 재질에 미치는 영향은 달라질 수 있다는 것을 확인하였다. 
Table 5. Culture result after disinfectants treatment

\begin{tabular}{|c|c|c|c|c|c|c|c|c|c|}
\hline \multirow{2}{*}{$\begin{array}{l}\text { Test } \\
\text { No. }\end{array}$} & \multicolumn{5}{|c|}{ Disinfectant treatment } & \multirow{2}{*}{ Fumigation } & \multirow{2}{*}{ Remark } & \multirow{2}{*}{$\begin{array}{l}1^{\text {st }} \text { Culture result } \\
\text { (36 hour) }\end{array}$} & \multirow{2}{*}{$\begin{array}{l}2^{\text {nd }} \text { Culture result } \\
\text { (36 hour) }\end{array}$} \\
\hline & $1^{\text {st }}$ & $2^{\text {nd }}$ & $3^{\text {rd }}$ & $4^{\text {th }}$ & $5^{\text {th }}$ & & & & \\
\hline 1 & - & - & - & - & - & - & Control 1 & BG & BG \\
\hline 2 & - & - & - & - & - & $30 \% \mathrm{HP}$ & Contro1 2 & - & - \\
\hline 3 & SW & - & - & - & - & - & Control 3 & BG & Do not conduct \\
\hline 4 & SW & - & - & - & - & $30 \% \mathrm{HP}$ & Control 4 & - & - \\
\hline 5 & DD & - & - & - & - & - & - & $B G$ & BG \\
\hline 6 & $\mathrm{BD}$ & - & - & - & - & - & - & & \\
\hline 7 & TD & - & - & - & - & - & - & & \\
\hline 8 & $\begin{array}{l}70 \% \\
\mathrm{EtOH}\end{array}$ & - & - & - & - & - & - & - & - \\
\hline 9 & DD & SW & - & - & - & - & - & - & - \\
\hline 10 & DD & $\begin{array}{l}70 \% \\
\mathrm{EtOH}\end{array}$ & - & - & - & - & - & - & - \\
\hline 11 & DD & $\begin{array}{l}70 \% \\
\mathrm{EtOH}\end{array}$ & SW & - & - & - & - & - & - \\
\hline 12 & $\mathrm{BD}$ & SW & - & - & - & - & - & - & - \\
\hline 13 & TD & SW & - & - & - & - & - & - & - \\
\hline 14 & DD & $\begin{array}{l}70 \% \\
\text { EtOH }\end{array}$ & - & - & - & - & - & - & - \\
\hline 15 & $\mathrm{BD}$ & $\begin{array}{l}70 \% \\
\mathrm{EtOH}\end{array}$ & - & - & - & - & - & BG & - \\
\hline 16 & $\mathrm{BD}$ & $\begin{array}{l}70 \% \\
\mathrm{EtOH}\end{array}$ & SW & - & - & - & - & - & - \\
\hline 17 & TD & $\begin{array}{l}70 \% \\
\mathrm{EtOH}\end{array}$ & - & - & - & - & - & - & - \\
\hline 18 & TD & $\begin{array}{l}70 \% \\
\mathrm{EtOH}\end{array}$ & SW & - & - & - & - & - & - \\
\hline 19 & DD & $\mathrm{BD}$ & - & - & - & - & - & - & - \\
\hline 20 & DD & $\mathrm{BD}$ & SW & - & - & - & - & - & - \\
\hline 21 & DD & $\mathrm{BD}$ & $\begin{array}{l}70 \% \\
\mathrm{EtOH}\end{array}$ & - & - & - & - & - & - \\
\hline 22 & DD & $\mathrm{BD}$ & $\begin{array}{l}70 \% \\
\mathrm{EtOH}\end{array}$ & - & - & - & - & - & - \\
\hline 23 & $\mathrm{BD}$ & TD & - & - & - & - & - & - & - \\
\hline 24 & $B D$ & TD & SW & - & - & - & - & - & - \\
\hline 25 & $B D$ & TD & $\begin{array}{l}70 \% \\
\mathrm{EtOH}\end{array}$ & - & - & - & - & - & - \\
\hline 26 & $B D$ & TD & $\begin{array}{l}70 \% \\
\mathrm{EtOH}\end{array}$ & SW & - & - & - & - & - \\
\hline 27 & DD & $\mathrm{BD}$ & TD & - & - & - & - & - & - \\
\hline 28 & DD & $\mathrm{BD}$ & TD & SW & - & - & - & - & - \\
\hline 29 & DD & $\mathrm{BD}$ & TD & $\begin{array}{l}70 \% \\
\mathrm{EtOH}\end{array}$ & - & - & - & - & - \\
\hline 30 & DD & $\mathrm{BD}$ & TD & $\begin{array}{l}70 \% \\
\mathrm{EtOH}\end{array}$ & SW & - & - & - & - \\
\hline
\end{tabular}

Abbreviations: $\mathrm{BD}=$ BruClean disinfectant (spray and wipes), $\mathrm{BG}=$ Bacteria grew, $\mathrm{DD}=\mathrm{DOCTOR}$ SOLUTION disinfectant (spray), $\mathrm{EtOH}=$ Ethyl alcohol (spray and wipes), HP= Hydrogen peroxide (spray and wipes), SW= Sterile water (spray and wipes), TD= TexQ disinfectant (spray and wipes). 


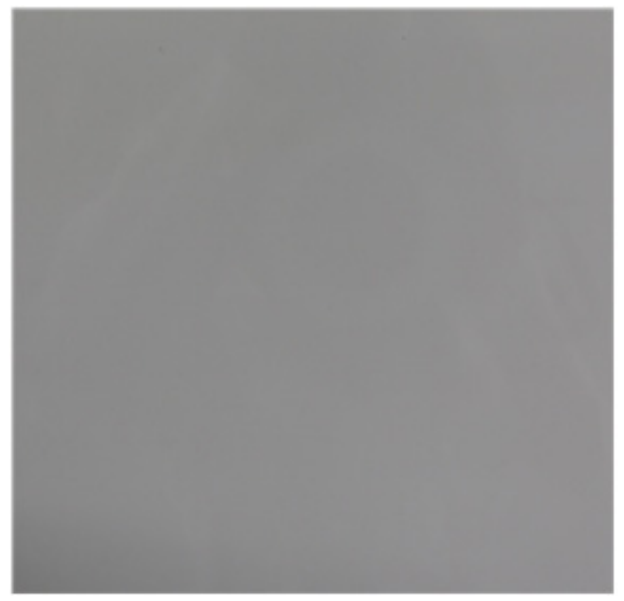

A. epoxy (normal)

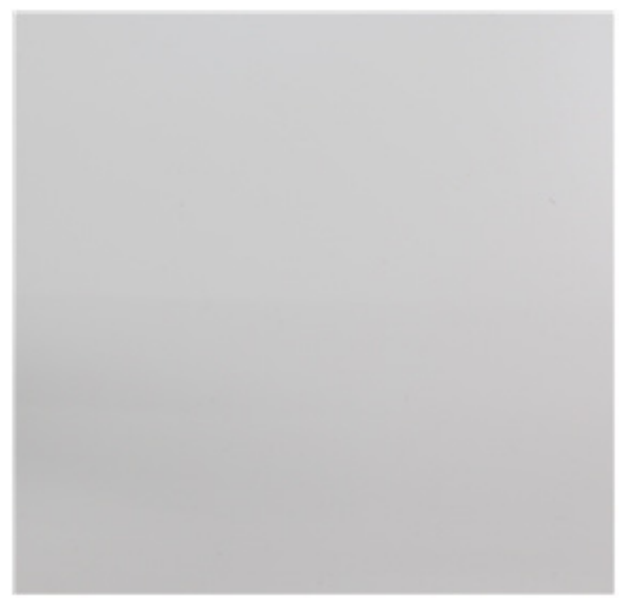

C. urethane (normal)

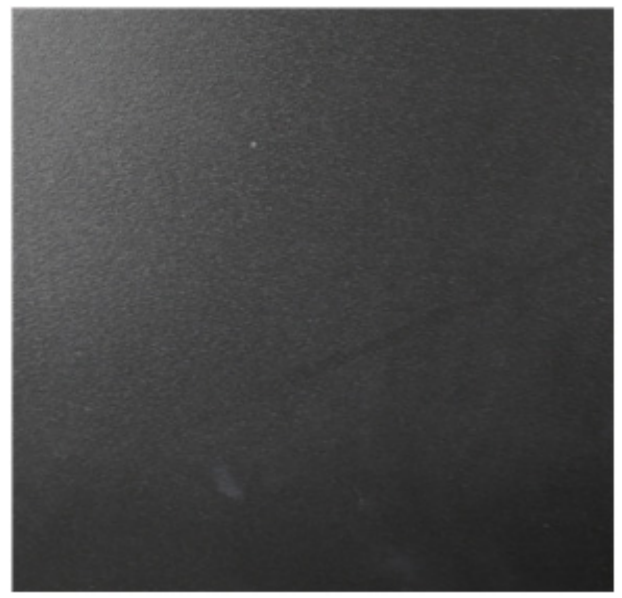

E. laboratory table (normal)

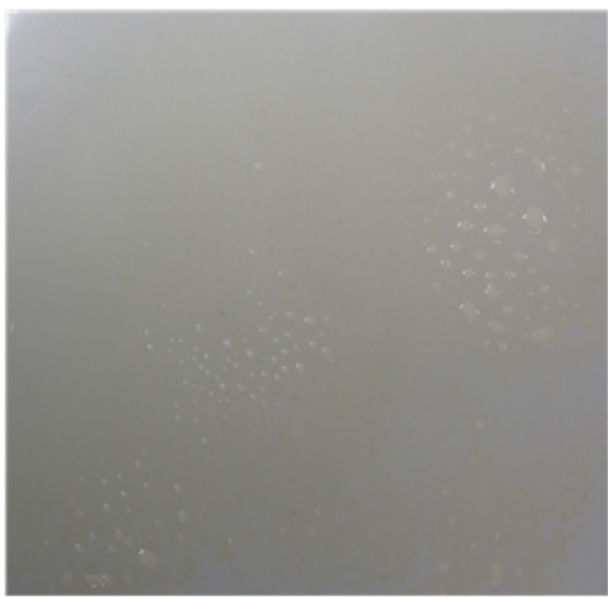

B. epoxy (deformation)

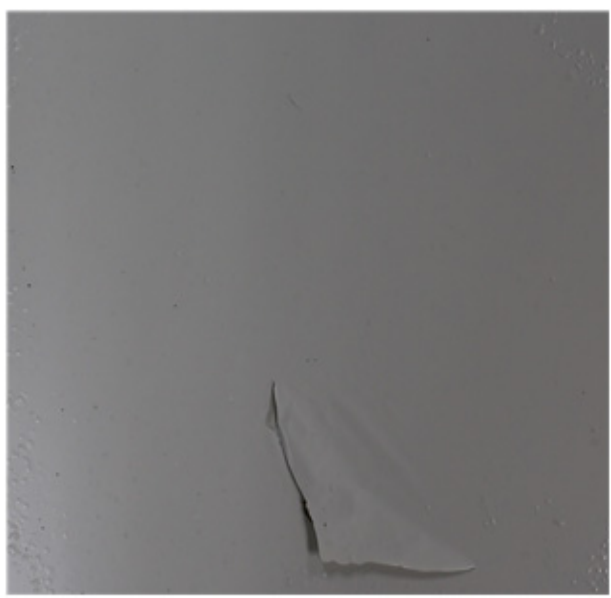

D. urethane (deformation)

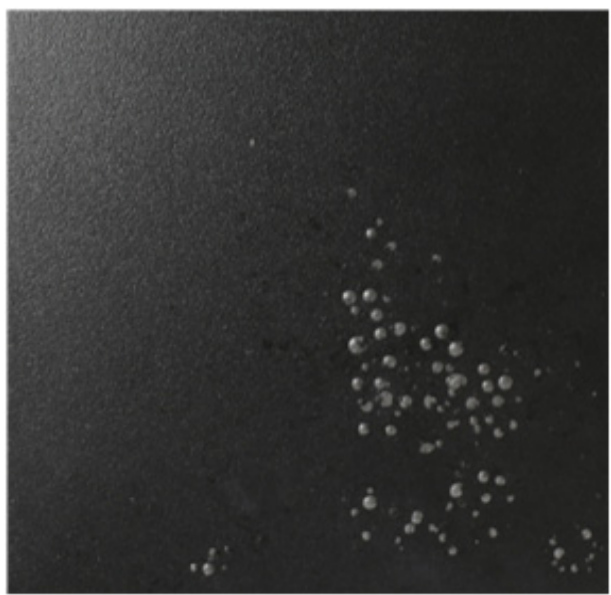

F. laboratory table (deformation)

Fig. 1. Surface observation of material after 7 sprays of $30 \%$ hydrogen peroxide. (A) (C) (E) The condition before disinfectant treatment is normal. (B) Epoxy surface showed color modulation from 1 time 30\% hydrogen peroxide spray. (D) Urethane surface peeling occurred from 4 times $30 \%$ hydrogen peroxide spray. (F) The surface of the laboratory table was observed to be bumpy surface from 3 times 30\% hydrogen peroxide spray. 


\section{DISCUSSION}

소독제는 적합한 용도에 맞게 선택해야 할 뿐만 아니라 사용 방법 또한 매우 중요하다. 소독제를 분사하는 것만으로는 균을 죽이거나 제거 하는 효과가 없었고, $70 \%$ 에틸알코올 등의 소독제를 사용하고 부직포 등에 적셔서 닦아 내는 것이 효과가 있었다. WHO에서도 소독제 를 분사하는 방식이 소독제가 바로 닿은 공간 이외는 소독 효과가 낮은 유사한 결과가 나왔다 (32). 따라서 소독 효과를 극대화하기 위해 서는 침지 혹은 충분한 양의 소독제를 적셔서 닦아 내는 것이 중요하다. 소독제를 선정함에 있어 소독제의 인체 독성에 대한 주의가 필요 하며, 소독제가 시설 및 내부 장비 등에 대한 영향을 사전에 고려해야 한다. 본 연구에서 확인한 결과 일반적으로 사용하는 농도의 소독제 는 시설, 장비, 기구 표면에 영향을 미치지 않았다. 실제 사용하는 농도는 아니지만, $30 \%$ 과산화수소의 경우 에폭시에 변색, 우레탄에 변 형 등을 일으켰다. 따라서 고농도의 과산화수소 취급에는 주의가 필요할 것이다. 소독제를 공기 중에 분무하는 소독 방법은 감염성 물질 에어로졸화 및 소독제 흡입 등의 위험성이 증가하는 것을 알 수 있다 (33). 이는 Park 등에 의해 살균 및 소독제 유해 성분에 노출되었을 때 폐 질환 증상이 확인되었다 (34). 최근에 2020년 1월에 발생한 코로나바이러스에 대한 '2020년 8월 코로나바이러스감염증-19 대응 집단시설·다중이용시설 소독 안내 제3-4판(중앙방역대책본부·중앙사고수습본부)'에 의하면 환경관리를 위한 환경부 승인 제품 중 사용 가능한 환경소독제는 WHO 등에서 제시한 차아염소산나트륨, $70 \%$ 에틸알코올, 제4급 암모늄 화합물, 과산화물로 만든 소독 제품 '77 방역 소독에탄올액(성수바이오텍, 대전)' 등 41종과 코로나바이러스 소독 가능한 환경부 승인제품 '케비사이드(위젠헬스케어, 서울)' 등 36 종해서 총 77 종이 지정 되었으며 소독 지침에 따라 각 기관별 사정에 맞게 공간(구역)소독 하고 있다. 또한 한국방역협회에서 중국 우 한에서 입국한 한국 교민을 위한 방역 소독도 환경부에 승인된 제4급 암모늄 화합물, 차염소산나트륨, $70 \%$ 에틸알코올 등이 코로나바이 러스-19의 소독 방역제로 사용되었음을 알 수 있었다(http://ikpca.co.kr). 2020년 2월 미국 화학위원회(American Chemistry Council; ACC)의 화학 살생물제 센터(Center for Biocide Chemistries; (BC)에서는 코로나바이러스감염증-19 확산 방지에 도움이 되 는 미국 환경보호청(United States Environmental Protection Agency; EPA)이 사전 승인한 'Accel ${ }^{\circledR}$ TB (Virox Technologies, USA)' 등 139 종 제품 목록을 발표하여 이러한 노력에 중요한 역할을 하였다 (35). 이어 2020년 3월 미국 환경보호청은 'Clorox ${ }^{\circledR}$ Performance Bleach1 (Clorox company, USA)' 등 83종 제품을 가지고 즉시 사용 가능(ready to use)하고 희석 가능(dilute)하며, 닦을 수 있는 (wipe) 소독 제품 목록을 공개하였다 (36). 미국 환경보호청에 따르면 코로나바이러스-19는 외피보유 바이러스(enveloped virus)이기 때문에 적절한 소독제로 죽이는 가장 쉬운 바이러스 유형 중 하나라고 언급하였다. 국가 공인 소독제 수는 77종, 미국은 83종으로 미국 이 1.1배 높은 편이다. 싱가포르는 세계보건기구(World Health Organization; WHO) 등 사용 소독제 성분인 4급 암모늄 화합물, 차아 염소산나트륨, 에틸알코올로 유사함을 알 수 있었다 $(37,38)$. Song 등은 병원시설에서의 실제 소독제 침지 와이프(disinfectantimpregnated wipes; DIW) 성능은 소독제 유효성분, 와이핑(wiping) 재질 간 상호 작용 등 다양한 매개 변수의 영향을 받으며 임상 적 용(clinical practice)에서도 DIW의 소독 효능 연구가 더 진행해야만 확인할 수 있다고 하였다 (39). 또한 Kampf 등의 22건의 연구분석 에 따라 인간 코로나바이러스(human coronavirus; HCoV)가 금속, 유리 등의 표면에 9일까지 살아 있을 수 있으며 1분 이내 62-71\% 에틸알코올, $0.5 \%$ 과산화수소, $0.1 \%$ 차아염소산나트륨을 사용한 표면 소독으로 바이러스를 비활성화할 수 있다는 연구 결과가 있었다 (40). 본 연구의 소독제 효과 시험에 사용한 시험균주 G. stearothermophilus는 탄저균과 같은 세균의 아포를 포함한 모든 형태의 미생 물을 파괴·사멸하는 과정의 무균 상태(감염성 물질 불활화, 생리활성 소멸 등)를 보이는 높은 수준의 멸균 되었음을 보여 주었다. 본 연구 를 통해 일반적인 국내 사용되는 소독제의 특성과 표면 소독 등의 오염 제거 효과를 알 수 있었다. 앞으로 이러한 소독 등 오염 제거 방법 은 오염의 특성과 병원체의 종류 그리고 오염 공간의 물리적 특성(크기, 환기장치 등)에 따라 소독제 선정과 소독 방법의 차이가 있을 수 있으므로 다양한 조건의 연구가 필요할 것으로 생각된다.

\section{ACKNOWLEDGEMENTS}

This work was supported by a grant (2015-P12001-00) from the Korean Healthcare Technology Research and Development project, Ministry for Health, Welfare and Family Affairs, Republic of Korea.

\section{REFERENCES}

1) Jeanne M. Disinfection and Decontamination: A Practical Handbook. London, New York: CRC Press, Taylor \& Francis Group, 2019. 
2) Block SS. Disinfection, sterilization, and preservation. $5^{\text {th }}$ ed. Philadelphia, PA: Lippincott Williams \& Wilkins, 2001.

3) Yoo JH. Review of Disinfection and Sterilization - Back to the Basics. Infect Chemother 2018;50:101-9.

4) Rutala WA, Weber DJ. Selection of the Ideal Disinfectant. Infect Control Hosp Epidemio/2014;35:855-65.

5) Kim HJ. KFDA-Cleared Disinfectants in Gastrointestinal Endoscopy. Korean J Gastrointest Endosc 2010;42:50-2.

6) The United States Department of Health and Human Services, Center for Disease Control and Prevention (CDC), National Institutes of Health. Biosafety in Microbiological and Biomedical Laboratories (BMBL) $5^{\text {th }}$ ed. Washington D.C.: CDC/NIH, 2009.

7) Hong KH. Viral Infections in Workers in Hospital and Research Laboratory Settings. Ann Clin Microbio/2017;20:27-34.

8) Lee KM, Jang WJ. Operation and management of biosafety research facilities. Korea: Air Cleaning Technology Press; 2016. p.1-10.

9) Seo SH, Jo SK, Kim HM, Lee CJ, Lee JS. Inactivation of Avian Influenza Viruses by Alkaline Disinfectant Solution. Journal of Life Science 2007:17:340-44.

10) Cho SH, Ju YS, Kang DH, Kim SG, Kim IS, Hong ST. Laboratory-acquired infections with hantavirus at a research unit of medical school in Seoul, 1996. Korean J Prev Med 1999:32:269-75.

11) Lee $\mathrm{CH}$, Jang EJ, Kwon DH, Choi H, Park JW, Bae GR. Laboratory-acquired dengue virus infection by needlestick injury: a case report, South Korea, 2014. Ann Occup Environ Med 2016:28:16.

12) Park SH, Kim YS, Jung YH, Choi SY, Cho NH, Jeong HW, et al. Outbreaks of Middle East Respiratory Syndrome in Two Hospitals Initiated by a Single Patient in Daejeon, South Korea. Infect Chemother 2016:48:99-107.

13) Cowling BJ, Park M, Fang VJ, Wu P, Leung GM, Wu JT. Preliminary epidemiologic assessment of MERS-CoV outbreak in South Korea, May to June 2015. Euro Surveill 2015;20:7-13.

14) Lee KM, Jang WJ, Choi YJ, Park KH. Emerging Infectious Diseases Require Biosafety Awareness and Procedures. J Bacteriol Viro/2016;46:104-7.

15) The 2018 MERS Response in the Republic of Korea. Korea Centers for Disease Control and Prevention 2018.

16) Chun BC, Yoo KH, Kim EK, Choi EK, Moon SJ, Lee SW. Epidemiologic investigation and the follow-up result for unexplained respiratory illness in a university laboratory. Public Health Weekly Report (PHWR), Korea Centers for Disease Control and Prevention 2018;11:1197-9.

17) Lee KM, Kim DW, Choi YJ, Park KH, Jang WJ. Survey on the Status of Biosafety Awareness among Domestic Biology Researchers. J Bacterio/ Viro/2017:47:96-101.

18) World Health Organization (WHO). Coronavirus disease 2019 (COVID-2019). WHO 2020; Situation report-47 (7 March 2020) https://mww.who.int/docs/default-source/coronaviruse/situation-reports/20200307-sitrep-47-covid-19.pdf?sfvrsn=27c364a4_4.

19) Kim JY, Choe PG, Oh YJ, Oh KJ, Kim JS, Park SJ, et al. The First Case of 2019 Novel Coronavirus Pneumonia Imported into Korea from Wuhan, China: Implication for Infection Prevention and Control Measures. J Korean Med Sci2020;35:e61.

20) Kim JY, Song JY, Yoon YK, Choi SH, Song YG, Kim SR, et al. Middle East Respiratory Syndrome Infection Control and Prevention Guideline for Healthcare Facilities. Infect Chemother 2015;47:278-302.

21) Division of Risk assessment and International cooperation. The update of COVID-19 in Korea (8 March 2020). Korea Centers for Disease Control and Prevention 2020. http://ncov.mohw.go.kr/tcmBoardView.do?brdld=\&brdGubun=\&dataGubun= \&ncvContSeq=353436\&contSeq=353436\&board_id=\&gubun=ALL.

22) Wood JP, Wending M, Richter W, Lastivka A, Mickelsen L. Evaluation of the Efficacy of Methyl Bromide in the Decontamination of Building and Interior Materials Contaminated with Bacillus anthracis Spores. App/ Environ Microbio/2016:82:2003-11. 
23) Chan KP. Control of Severe Acute Respiratory Syndrome in Singapore. Environ Health Prev Med 2005;10:255-9.

24) Otter JA, Mepham S, Athan B, Mack D, Smith R, Jacobs M, et al. Terminal decontamination of the Royal Free London's high-level isolation unit after a case of Ebola virus disease using hydrogen peroxide vapor. Am J Infect Control 2016:44:233-5.

25) Advisory Committee on Dangerous Pathogens (ACDP). Management of Hazard Group 4 viral hemorrhagic fevers and similar human infectious diseases of high consequence. Health and Safety Executive (HSE), United Kingdom 2005.

26) Korea Centers for Disease Control and Prevention. Laboratory biosafety guidelines. $2^{\text {nd }}$ ed. 2016.

27) Rutala WA, Weber DJ. the Healthcare Infection Control Practices Advisory Committee (HICPAC). Guideline for Disinfection and Sterilization in Healthcare Facilities, 2008. Department of health and human service, Washington 2008.

28) Labour Department. Chemical Safety in the Workplace-Guidance Notes on Safe Use of Chemical Disinfectants $1^{\text {st }}$ ed. Hong Kong Special Administrative Region (HKSAR) Government, 2007. https://www.labour.gov.hk/eng/public/os/C/ Disinfectants.pdf

29) Bae YM, Heu SG, Lee SY. Inhibitory Effect of Dry-Heat Treatment and Chemical Sanitizers against Foodborne Pathogens Contaminated on the Surfaces of Materials. J Korean Soc Food Sci Nutr 2009;38:1265-70.

30) McDonnell GE. Antisepsis, Disinfection, and Sterilization: Types, Action, and Resistance. $2^{\text {nd }}$ ed. Washington, District of Columbia: ASM Press, 2017

31) The United States Pharmacopeial (USP). General Information 1072, Disinfectants and Antiseptics. 2012; 35:619-22.

32) World Health Organization (WHO). Cleaning and disinfection of environmental surfaces in the context of COVID-19, Interim guidance (16 May 2020). https://www.who.int/publications/i/item/cleaning-and-disinfection-of-environmentalsurfaces-inthe-context-of-covid-19

33) Central Disaster Management Headquarters • Central Disease Control Headquarters. 「COVID-19 Response」 Disinfection Guidelines to Prevent the Spread of COVID-19 at Public and Multi-Purpose Facilities [ver. 3-4] (19 August 2020). http://ncov.mohw.go.kr/duBoardList.do?brdld=2\&brdGubun=25.

34) Park EJ, Seong E, Kang MS, Lee GH, Kim DW, Han JS, et al. Formation of lamellar body-like structure may be an initiator of didecyldimethylammonium chloride-induced toxic response. Toxicol App/ Pharmaco/2020;404:115182.

35) The American Chemistry Council (ACC). Center for Biocide Chemistries (CBC). Novel Coronavirus (COVID-19)-Fighting Product (9 March 2020). https://media.clemson.edu/research/safety/CBC\%20COVID19\%20Product\%20List\%5B4\%5D.pdf.

36) The United States Environmental Protection Agency (EPA). List N: EPA's Registered Antimicrobial Products for Use against Novel Coronavirus SARS-CoV-2, the Cause of COVID-19 (3 March 2020). Office of Chemical Safety and Pollution Prevention (OCSPP). https://mww.coronavirus.kdheks.gov/DocumentCenter/Niew/345/EPAs-Registered-AntimicrobialProducts-for-Use-Against-Novel-Coronavirus-SARS-CoV-2-the-Cause-of-COVID-19-PDF.

37) National Environment Agency (NEA). Interim Guidelines for Environmental Cleaning and Disinfection of Areas Exposed to confirmed Case(s) of COVID-19 in Non-Healthcare Premises (10 March 2020). Government of Singapore. https://www.nea.gov.sg/our-services/public-cleanliness/environmental-cleaning-guidelines/guidelines/guidelines-forenvironmental-cleaning-and-disinfection.

38) World Health Organization (WHO). Water, sanitation, hygiene and waste management for the COVID-19 virus. Technical brief (3 March 2020). https://www.who.int/publications/i/item/WHO-2019-nCoV-IPC-WASH-2020.4.

39) Song X, Vossebein L, Zille A. Efficacy of disinfectant-impregnated wipes used for surface disinfection in hospitals: a review. Antimicrob Resist Infect Contro/2019:8:139.

40) Kampf G, Todt D, Pfaender S, Steinmann E. Persistence of coronaviruses on inanimate surfaces and their inactivation with biocidal agents. J Hosp Infect 2020;104:246-51. 